\title{
A Brief History of Maritime Econometrics, 1934-2012
}

\author{
Alexandros M. Goulielmos ${ }^{1,2}$ \\ ${ }^{1}$ Department of Maritime Studies, Faculty of Maritime and Industrial Studies, University of Piraeus, \\ Piraeus, Greece \\ ${ }^{2}$ Shipping Department, Business College of Athens, Athens, Greece \\ Email: ag@unipi.gr, am.goulielmos@hotmail.com, agoulielmos@bca.edu.gr
}

How to cite this paper: Goulielmos, A.M (2019) A Brief History of Maritime Econometrics, 1934-2012. Modern Economy, 10, 730-756.

https://doi.org/10.4236/me.2019.103050

Received: January 16, 2019

Accepted: March 17, 2019

Published: March 20, 2019

Copyright $\odot 2019$ by author(s) and Scientific Research Publishing Inc. This work is licensed under the Creative Commons Attribution International License (CC BY 4.0).

http://creativecommons.org/licenses/by/4.0/

\section{(c) (i) Open Access}

\begin{abstract}
This article reviews the seminal econometric ${ }^{1}$ models published by maritime economists between 1934 and 2012, indicating the main mistakes committed during this period, so that future research can avoid them. The errors were spurious regression, identification and the false assumption that maritime markets are sufficiently efficient, if co-integrated. Three further mistakes are noted: the belief that a shipping firm is its vessel; the assumption that a random walk is appropriate for modeling tanker markets, and the assumption that shipping markets are random and linear. Koopmans was correct (in 1939) in stating that the discrepancy (surplus/deficit) between supply and demand for ship space determines freight rates, something that passed unnoticed until recently. The papers reviewed cast in four centers -on the basis of the academic domicile of their authors: 1) the pioneering Dutch Center, 1934-1939, 2) the Zannetos Model, 1966, 3) the Norwegian Center, 1976-2012, and 4) the Beenstock-Vergottis Model, 1985-1993 and English Center, 19872002. Unfortunately, each new shipping model rejected almost all previous ones and consequently the research did not build a clear picture. Moreover, maritime markets are not perfectly competitive, and most maritime economic concepts need a re-definition, including: shortrun, shipowners expectations and marginal cost.
\end{abstract}

\section{Keywords}

Shipping Econometric Models, A Critical Survey 1934-2012, Suggestions for Further Research

${ }^{1}$ Econometrics is the science dealing with how we can measure the impact of economic policy etc. on the economy using statistical methods. 


\section{Introduction}

Models are important because they attempt to represent reality. A model is a simplified representation of actual phenomena, and has three specific purposes: to explain, to predict and to control reality. In econometric language, this triptych entails three targets: 1) a structuraP analysis, 2) a forecasting and 3) policy evaluation.

There are four main types of model (Figure 1).

The first type was used by Adam Smith (1776) [2] and involved the invisible hand and the division of labor. Physical models represent a real-world system with a physical entity. Geometrical models use diagrams, few variables, including supply and demand. Such models appeared in shipping economics, because the price or freight rate is theoretically determined by supply and demand for hiring ship space. Algebraic models provide systems of equations, needing econometric methods, which can be linear or non-linear (Intriligator, (1978) [1]).

Historically, freight markets were a popular subject of shipping economics and gained priority in shipping econometrics (e.g. Koopmans, (1939) [3]; Zannetos, (1966) [4]; Beenstock and Vergottis, (1993) [5]; Kavussanos, (1996) [6]. Moreover, there were often cycles of freight rates. In this industry, supply and demand drive each of its own way independently and supply must adapt to (unforeseen) changes in demand, which in turn depends on global seaborne trade. Demand cannot adapt to supply, unless the freight rate is so high so that to affect the final price of the goods in the market.

Two economists, who started shipping economics, became Nobel laureates in economics: Jan Tinbergen in 1969 and Tjalling Koopmans in 1975. Three early shipping economics books influenced theory: Koopmans' [3] in 1939; Zannetos' [4] in 1966, and (3) Beenstock and Vergottis' [5] in 1993. In addition, these books triggered a number of papers (Veenstra and De La Fosse, (2006) [7]). Zannetos' book [4] stimulated at least 43 papers by 2006, of which half dealt with freight rates.

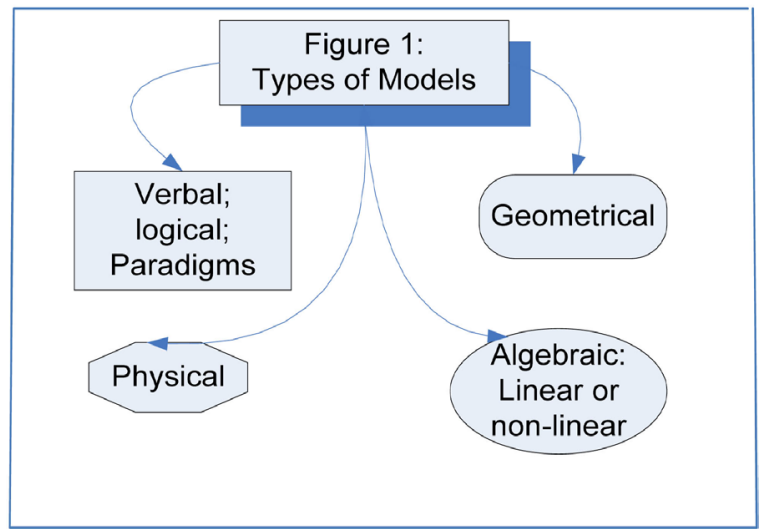

Figure 1. Four main types of model. Source: Intriigator (1978) [1].

${ }^{2}$ Structural refers to a system of simultaneous equations with endogenous variables-defined below-on the right hand side. Reduced form is derived (algebraically) from structural. Structural equations are equations interlinked and each includes several variables. 
Shipping is an international industry, and as such attracted the close attention of international regulatory bodies: the United Nations (UN) and its specialized agencies: the International Maritime Organization (IMO), the International labor office (ILO); also the Organization of economic cooperation and development and European Union (EU) among others. It is an over-regulated industry. These bodies focused on legal, socio-managerial as well technical issues: safety, security, sea pollution, climate change, and piracy. In Talley (2012) [8], 18\% of the papers reviewed dealt with this limited range of topics. This was a result of the opinion that shipping has a negative impact on sea environment, climate, crew and passenger lives, and on third party property. This opinion was confirmed by occasional high profile incidents. Shipping management became more complex than it used to be (Goulielmos, (2002) [9]).

A flood of papers appeared eventually on port economics as time passed-by. Port economics gained an equal place in published papers alongside shipping economics and shipbuilding ${ }^{3}$. A popular new subject also emerged: Maritime Logistics ${ }^{4}-\mathrm{ML}$.

Shipping econometricians were slow to adopt available econometric methods. Most applications emerged from doctoral dissertations (Zannetos, (1966) [4]; Glen, (1987) [10]; Vergottis, (1988) [11]; Kavussanos, (1992) [12]; Psifia, (2006) [13] and others.

Econometrics, like economics, first dealt with economic epidemics, or "business-cycles". The most painful cycles were the "Great Depression" of 1929 to 1937 and the Global Financial Crisis followed by the end of 2008 to 2016. There have been three major depressions in shipping since the Great Depression: 1) in 1973, with a crisis in tankers, as a result of the first oil crisis, and in 1979, after the second energy crisis, 2) in 1981 to 1987, a dry cargo depression, and 3) from 2008 to 2016 due to the banking crisis in USA, affecting both dry and liquid cargoes.

Shipping, with its frequent cycles, (Stopford, (2009) [14]), attracted the attention of Tinbergen (80 years ago) [15], of Koopmans (1939) [3] and of Zannetos (1966) [4], and of many others since. However, forecasting shipping cycles remains an enigma.

The paper surveys of the econometric models applied to shipping economics, between 1934 and 2012, without repeating material from our two other papers which covered the period 1996 to 2016 [16] [17], unless this is absolutely necessary.

The paper is organized in seven parts. Part 2, describes the evolution of econometrics; Part 3 presents the models of the Dutch Center, 1934-1965. Part 4,

\footnotetext{
${ }^{3}$ Shipbuilding, (as well Cruising), left behind! Shipbuilding belongs also to manufacturing. ${ }^{4} \mathrm{~A}$ branch of maritime economics dealing with all available means of transport in a combination strategy. ML aims at the minimum cost of containers' transport from point of production to point of consumption, including information (GPS). ML emerged when sea transport wanted to provide door-to-door and just-in-time services. It combines: ports, sea, air, land, rivers; storage depots and assembly centers. It seeks to minimize transport time. It deals also with such issues like the management of empty containers.
} 
presents Zannetos' Model, 1966. Part 5, presents the models of the Norwegian Center, 1976-1985. Part 6, analyses the Beenstock and Vergottis Model, 1985-1995, and the models of the English Center, 1986-1995; 2002. Part 7, provides a critique of the models presented, and Part 8 , suggests further research.

\section{The Evolution of Econometrics}

The most popular econometric tool is "linear regression", invented by Francis Galton in 1885 [18], who is also the father of the concept of correlation 1889.

In rigorous terms, a linear regression is denoted as:

$$
y_{t}=\alpha+\beta x_{t}+u_{t}
$$

where the error term $u_{t}$ is assumed to be identically and independently distributed round its mean, with 0 mean and variance equal to $\sigma^{2}$. The exact form of any regression, (i.e. estimating the parameters $\alpha$ and $\beta$ ) is determined mathematically by the method of least squares, devised by both Legendre in 1805 and Gauss in $1809^{5}$.

Frisch (1938) [19] was the founding father of econometrics. Modern econometrics was further established by Haavelmo (1943) [20], 1944 [21], and formalized by the research carried out by the Cowles Commission (Qin, (2013) [22]. In 1933, Cowles [23] established the commission "to gather and analyze market data, as he was frustrated by the imprecision of what passed for financial advice" (Mandelbrot and Hudson, (2006/8) [24]).

The work done by the Cowles Commission was an intellectual success, (but an) empirical failure (Heckman, (2000) [25]; Qin, (2013) [22]). The work was closely associated with the structural approach pioneered by Frisch (1938) [19], who suggested models with many variables, attempting to explain changes in a variable by current or past values of other (explanatory) variables (Brooks, (2014) [26]).

In 1958, econometrics abandoned structural models, i.e.

$$
y=\alpha+\beta x
$$

with exogenous ${ }^{6} x$ and explanatory variable(s) fixed over repeated samples (Brooks, (2014) [26]). If the dependent variable is linearly determined by $k$ independent variables: $x_{1}, x_{2}, \cdots, x_{k}$, and there is one endogenous ${ }^{7}$ variable, then Equation (2) can be written:

$$
y_{t}=\alpha+\beta x_{t}
$$

where $t=1, \cdots, n$ (i.e. a linear static function applicable to time series).

More specifically, in "structural equation modelling" (SEM), each endogenous variable has its own equation. Econometricians considered Equation (3) insufficient, and added a (stochastic) error term ${ }^{8}, u_{t}$, turning it into a statistical ${ }^{5}$ This method caused a debate between the two authors on the paternity of the method.

${ }^{6}$ An exogenous variable is the one whose values are determined outside the equation(s), un-correlated with the error term.

${ }^{7}$ An endogenous variable is the one whose values are determined within a system of equations.

${ }^{8}$ Econometricians thus admitted inaccuracy (errors) in forecasting and thus ruled-out determinism! 
model.

A causal relationship was first considered as coming from $x^{\prime}$ variables to $y$. But, causality ${ }^{9}$ can also be from $y$ to $x$. The variables may thus be interrelated in a system of linear simultaneous equations. An endogenous variable can also appear on the right hand side of an equation creating the simultaneity problem. This means that if a (stochastic) price and quantity appear in two equations, it is impossible to estimate them validly using ordinary least squares, and maintaining that $\mathrm{x}$ and $\mathrm{u}$ are independent, and errors uncorrelated with explanatory variables [26].

SEM, however, was popular in published papers, and books, until 1970, accounting for $20 \%$ in 1951, rising to $48 \%$ in 1959-1966 and falling back a little to $33 \%$ in 1968-1970 [22].

There is also a feedback mechanism operating between many economic variables. Economic data should then be described as a system of (simultaneous) relations. A SEM is then properly used to describe relationships among random economic variables.

\subsection{What Is Random 10 ?}

The property of randomness in a variable, or time series, should be tested (e.g. by the Jarque-Bera test), and when tested the results should be taken into account. A diagrammatic test of randomness is presented in Figure 2, using MATLAB and "Rescaled Range Analysis" ${ }^{11 "}$. It shows the first logarithmic differences between a random variable (e.g. Baltic Panamax Index-BPI) (red line) and its actual representation (blue line).

As shown, the supposedly random curve of daily BPI for 1999-2012 (blue line) departs from random (red line).

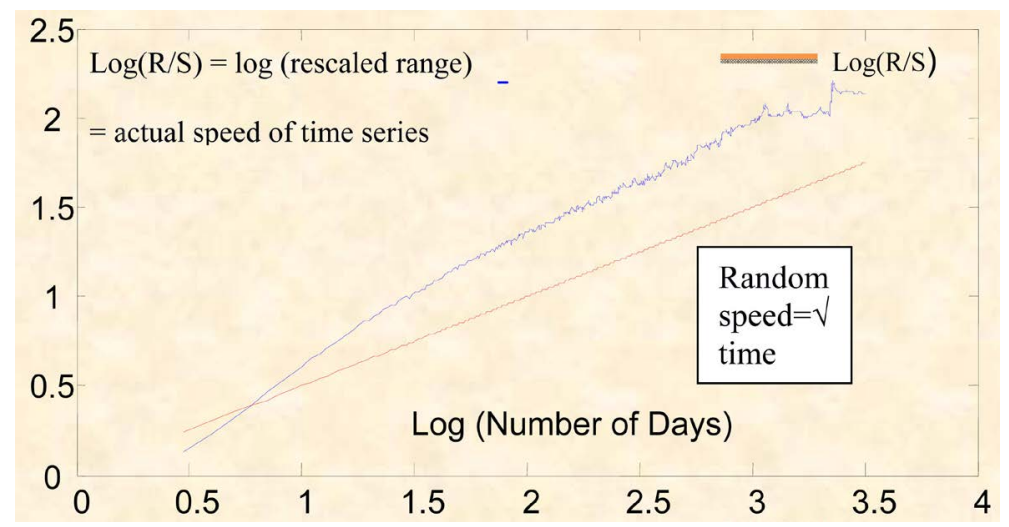

Figure 2. The actual speed of BPI time series and that of its Random Walk (1999-2012).

${ }^{9}$ The classical linear regression model assumed that the explanatory variables are non-stochastic. But this assumption can be violated. There are also errors-in-variables and the use of proxies.

${ }^{10} \mathrm{~A}$ common term is random walk. This is used when the current value of a series is the previous value perturbed by a white noise error term.

${ }^{11}$ A method developed by Hurst H E (in 1951) to determine long-memory effects and fractional Brownian motion. A measurement of how distance covered by a particle increases over longer and longer time scales. For Brownian motion the distance covered increases with the square root of time. 


\subsection{The Identification Problem}

Haavelmo (1943) [20] drew attention to the identification problem connected with SEM and the associated estimation problem (i.e. simultaneity bias) of OLS estimators. Marschak (1946) [27] tried to combine theoretical and empirical research. Econometric steps were then formalized: 1) a model specification, 2) identification and 3) estimation. Finally, SEM is the most general form of a structural model, having the conceptual adequacy of the Walrasian general equilibrium system.

SEM was then transformed into a reduced form, which is more useful for forecasting. The main method adopted was the maximum likelihood, which became the limited information maximum likelihood model, with associated and appropriate computing methods (Epstein, (1987), [28], (1989) [29]). This is a method for estimating the parameters of nonlinear models, based on the construction and maximization of a likelihood function.

\subsection{Dynamic Models, 1975-1980}

Three movements occurred during late 1970s in econometrics: 1) the "rational expectations" move in macroeconomics; 2) $\mathrm{VAR}^{12}$ (Sims, (1980) [30] and 3) the dynamic specifications move (pioneered in the London School of Economics). These three movements re-instated the importance of dynamic models (Hendry, (1980), [31]). This was important because static had never being realistic.

Rational expectations are based on the principle that people make, on average, correct guesses about future, using all available and relevant information. In order to have a perfect foresight, information must be complete, and the uncertainty zero... Models that are related to VAR are: $\mathrm{ARMA}^{13}, \mathrm{VECM}^{14}$ and $\mathrm{VMA}^{15}$.

Dynamic models include lagged or differenced terms of the dependent or independent variables. A new methods to estimate these models was the two stages least squares developed by Theil (1953) [32] and Basmann (1957) [33]. The method was used to estimate parameters called instrumental variables, developed by Sargan (1958) [34], 1959 [35]); also the SUR method emerged developed by Zellner (1962) [36 $]^{16}$. IV are correlated with the variables they replace, but not with error term. SUR applied to shipping by Kavussanos M. SUR is suitable for models with movements of several highly related dependent variables, using a time series regression, and at the same time, allowing correlation in error terms.

\footnotetext{
${ }^{12} \mathrm{~A}$ time series specification with many variables, where the values of lagged variables of all variables appear on RHS in all equations of the unrestricted model.

${ }^{13} \mathrm{~A}$ VAR model with lagged values of error term in each equation.

${ }^{14}$ Embedded into a VAR framework for relationships (short- and long-term) between a set of variables to be modelled simultaneously.

${ }^{15} \mathrm{~A}$ multivariate time series model, where series is expressed as a combination of lagged values of a vector of white noise processes.

${ }^{16}$ Instrumental variables are used when we replace endogenous variables on the RHS of a regression.
} 


\subsection{Stationary Maritime Time Series}

Shipping economists used non-stationary variables in their models. Using such methods one can easily fit regressions using levels of co-trending, but unrelated variables, and find reasonable goodness of fit, and heavy serial correlation, even though this correlation is spurious (Phillips, 1986) [37])!

A regression involving two or more independent non-stationary variables, where the estimates of the slopes appear highly significant in standard statistical tests, can have highly significant t-ratios, even though in reality there is no relationship. This restriction to the method was first considered in the 1970s, and appeared in shipping models 10 years later. Because of this phenomenon, the conclusions of any paper published before 1990 must be considered invalid. The time series involved did not have constant means, and included a variance and an auto-covariance.

\subsection{Co-Integration: The Great Breakthrough!}

After 1986-1987, econometricians used methods to analyze time series with many co-integrated variables/equations, (i.e. variables showing a fixed relationship in the long-run), with error corrected (i.e. variables that were stationary/1st differenced-which were combined with a term capturing movements back to their long-run equilibrium) (Engle \& Granger, (1987), [38]).

Maritime economists adopted these innovative approaches roughly six years after their first appearance. Many maritime economists incorporated assumptions into their models, including the idea that markets were efficient and that people (traders) have rational expectations. In combination, these suggest that asset prices, (or their natural logarithms), follow a random walk (with or without drift) (with unpredictable differences).

Kavussanos and Alizadeh-M (2002) [39] [40] rejected previous shipping models, which used co-integration, (e.g. Hale and Vanags' (1992) [41]), and argued that co-integration is a sufficient, but not necessary ${ }^{17}$, condition for an efficient market. They used a generalized conditional heteroscedastic model (GARCH-M), previously developed by Campbell and Shiller, (1987) [42]). Two dry cargo markets (new-buildings and second hand) were found not to be efficient (due to stable risk premiums) using data from 1980 to 1997.

They assumed that time charters (of 12 months) should reflect the weighted average of the expected monthly (spot) freight contracts over the next 12 months, if they were efficient. They applied the expectations hypothesis of term structure (EHTS). Their results did not support the hypothesis because returns were excessively volatile. This implies that shipowners prefer to be in less volatile markets, but between 2003 and 2008 shipowners preferred to be in the spot market with very high profits, extreme volatility, and more risk.

Kavussanos and Alizadeh-M [40] also showed that the dry bulk shipping freight rate market is not efficient and does not price risk as expected, because of

${ }^{17}$ This confirmed by e-mail to author by Prof. Kavussanos. 
the way that shipowners perceive risk; they are prepared to suffer a loss to secure a contract for a longer duration. Between 2003 and 2008, shipowners found it very rewarding to be in the spot market, but after the end of 2008, they regretted it. It can be seen that the level of net profit is decisive, and its variability is a secondary matter. The level of profit seems to overshadow risk. Shipowners prefer to accept a lower time charter rate-lower than spot-if they anticipate a falling spot rate in the future.

Certain models presuppose that investors should be compensated for taking more risk by getting a higher return. We argue that in shipping when seeking profit risk is ignored. Engle et al. (1987) [43] suggested applying ARCH-M model. However, GARCH-M ${ }^{18}$ was more popular, and replaced

$$
\text { ARCH-M }=Y_{t}=m+d V_{t-1}+u_{t}
$$

If $d>0$ (then a risk premium exists), and if it is statistically significant, then increased risk leads to a rise in the mean return.

Goulielmos (2009) [44] argued that the Aframax markets showed different levels of long term volatility, and risk, with the second hand ship market (alpha = 1.32) (shorter) safer (less volatile) followed by the new-buildings market (longer) $($ alpha $=1.30)$. This means that in shipping shorter-run investors run lower risks than longer-term ones, though the above alphas are close. Alternatively, in practice charterers avoid long-term time charters out of fear that a marine accident may happen. This is a matter of concern where overage tankers (say more than ten years of age) are involved. This suggests a testable hypothesis that has not been adequately examined: "Will shipowners prefer to be in the spot market when profits are very high, even if the market is then more volatile and of a higher risk?"

In econometrics, the sequence of the events was: 1) the "autoregressive model" $\left(\mathrm{AR}^{19}\right)$, which replaced the multivariate and inappropriate structural model. 2) A class of time series models were introduced: the "AR integrated moving average" (=ARIMA $\left.{ }^{20}\right)$, associated with Box and Jenkins (1976) [45].

\section{The Dutch Center, 1934-1965}

The earliest shipping models produced by Dutch Center were due to Tinbergen ${ }^{21}$ and Koopmans ${ }^{22}$, who also played an important role in the development of Eco${ }^{18} \mathrm{GARCH}-\mathrm{M}$ is a dynamic model for volatility, where standard deviation- $\sigma$ enters into the generating process; $\sigma$, however, does not reflect risk as good as alpha coefficient- $\alpha$.

${ }^{19} \mathrm{AR}$ is a time series model where current value of a series is fitted with its previous values.

${ }^{20}$ ARIMA is a univariate time series model derived from a generalization of ARMA for a stationary-made process after differenced it $\mathrm{d}$ times.

${ }^{21}$ Mathematician and physicist, with numerous publications (1935-1952); 50\% of them dealt with business cycles (1935-1939); one with econometrics (1951) and one with the theory of economic policy (1952)—considered influential-1939-1975. He made significant contributions to the concept of "shadow prices". He was also known for his macro-dynamic model, and especially for that of US economy (1939), which is the first major econometric effort to model "business cycle". A subsequent methodological debate over his models with Keynes, played a crucial role for him and for the wider formalization of econometrics (Qin, (2013) [22]).

${ }^{22} \mathrm{He}$ was a student of Tinbergen and physicist. 
nometrics (Qin, (2013) [22]). They are considered fundamental contributors to maritime economics (Veenstra and De La Fosse, (2006) [7]).

\subsection{Tinbergen's 1934 Model}

Tinbergen $(1934 ; 1959)$ [15]) related freight rates to changes in demand, (stated in ton miles), which he considered to be perfectly inelastic. Using data from 1880 to 1911 , and to changes in supply (also in ton miles) as well as laid-up tonnage, he showed that

$$
S=K^{a} P^{-b} F^{g}
$$

where $P=$ the price of fuel (coal) -other costs assumed constant- and $K=$ the tonnage level. The equilibrium condition is that demand equals supply.

Solving (5) at equilibrium for freight rate gives a linear regression:

$$
F=e_{1} D-e_{2} K+e_{3} P
$$

where $e_{1}=1 / g, e_{2}=a / g$ and $e_{3}=b / g$. This states that the freight rate is determined, at equilibrium, by demand, $D$ for tonnage, where $K=$ level of existing tonnage (i.e. supply) and $P=$ cost of fuel.

Equation (6) is a rudimentary timeless (no lags) model that omits various factors. The expression of supply and demand in ton-miles indicates that Tinbergen understood the importance of distance and speed. Dynamic models, i.e. with lags, appeared a few decades later. This is a shortrun model depending on laid up tonnage, which is a shortrun variable, reacting on changes in demand in one to three months. Demand for extra tonnage reacts first, and supply reacts in a second cycle by new constructions (in the long run). New construction is restricted by construction time (one to two years).

Economists generally use a catch all phrase for omitted factors, customarily assuming that do not change-others things being equal, the ceteris paribus assumption. Fuel cost may have exerted a direct influence on supply, meaning that it was included twice. The elasticity of supply and demand curves, at equilibrium, is essential in setting the freight rate, and should be included. Tinbergen argued that the freight rate reverts ${ }^{23}$ to its average.

The concept of equilibrium $(\mathrm{D}=\mathrm{S})$ used by shipping economists, first emerged in Physics in the work of Canard in 1801 (Schweitzer (ed.), (2002), [47]). Estola (2002) [48], argued that equilibrium means a "balance of forces". Economists adopted the term without providing a strict definition, and shipping economists did the same.

\subsection{Koopmans' Model}

Koopmans (1939) [3] modeled, at equilibrium, the demand for tanker services as equal to supply (in ton miles), i.e.

$$
D=K(F / P)^{g}
$$

${ }^{23}$ If the system was up in the previous period, it is more likely to be down in next period (Peters, (1996) [46])? 
where $P=$ costs (all costs). Supply is proportional to fleet size $(K)$ and to the ratio of freight rate to costs. Coefficient $g$ was found to be 0.15 , indicating a strong influence of laid-up tonnage on elasticity of supply. Koopmans also showed the effect of laid-up tonnage on freight rates accounting for short-run ups and downs. He also, related ship values to freight rates for tankers and linked the freight market with shipbuilding and scrapping. Koopmans' model is presented diagrammatically in Figure 3.

Figure 3 presents a diagrammatic determination of short-run tanker freight rates, $\mathrm{F}_{1-3}$. The supply curve, (expressed in ton miles), is initially (on left) perfectly elastic (part sf), because the available tonnage is not hired and some ships are laid-up. If the demand curve intersects this part of the supply curve, the impact on equilibrium freight rates will be negligible.

If demand increases, as shown by the shift of demand curves to the right, and intersects the right hand part of the supply curve, the fleet is fully employed. Increases in demand gradually draw into use all sea-worthy tonnage. The full impact of increased demand, in the shortrun, passes entirely to freight rates, no more tonnage is available (not even from shipbuilding). Certain factors in the ceteris paribus cupboard, like: average speed of ships, ships lost, ships scrapped and ships converted, are assumed to have exerted all their influence on supply and to remain constant at equilibrium.

The construction of additional ships requires time, which, by definition, is beyond the shortrun. Equilibrium is delayed and demand outstrips supply until supply responds. The time taken to reach equilibrium varies. There are waiting and construction times for new buildings, also variable, depending on whether a boom or a depression is on the way. The time span may be from a few months to a few years.

The various factors mentioned above show that a simple two-variable model-like those of Koopmans and Tinbergen-left out a number of factors. Tinbergen and Koopmans indirectly incorporated sea distances, scrapping, and laid-up tonnage. Sea distances and lay-up tonnage play an important role, but the impact the speed of ships in low steaming is completely ignored.

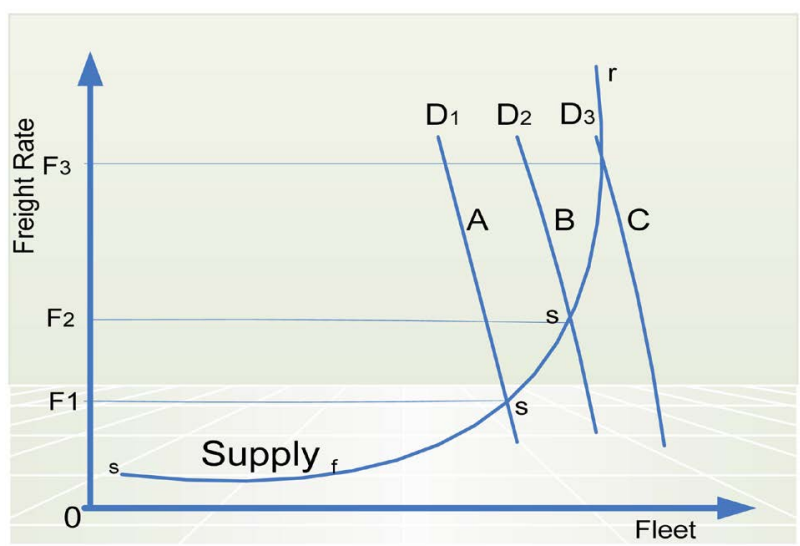

Figure 3. Short-run equilibrium freight rate determined by supply and demand (tankers). Source: inspired by Koopmans (1939) [3]. 
Figure 3 is a presentation tool, and has little to do with a rapidly changing real world. Figures are invented by economists to focus on two variables, in demand and supply (a two dimensional space). This is a market photograph, valid only at the specific moment when it was taken. To approach reality, time must be introduced into the models.

In Figure 3, equal shifts in demand, $\mathrm{AB}=\mathrm{BC}$, correspond to very unequal increases in freight rates, because demand is absolutely inelastic at this stage: $\mathrm{F}_{1} \mathrm{~F}_{2}$ $<\mathrm{F}_{2} \mathrm{~F}_{3}$. This explains why there are large fluctuations in freight rates (Evans (1994) [49]). There is a saying that "shipping creates great fortunes, but also great misfortunes". For example, Onassis gained a freight rate six times the value of his ship for a single trip during the Korean War (1951). Another shipowner, from Sweden, gained a freight rate equal to $\$ 1 \mathrm{~m}$ for one trip using a super tanker...

A valid hypothesis made by Koopmans [3] was not tested, due to lack of suitable data. He argued that expectations about the equilibrium of supply and demand for ship services, for a few years ahead, exert the most decisive influence on tanker buildings. Goulielmos (2014) [50] tested this, using figures ${ }^{24}$ for the surplus of supply over demand. The correlation coefficient was high $(=0.84)$ between surpluses in demand and supply, and time charters (1976-1988).

\section{Zannetos' Model, 1966}

Zannetos' model is presented in Figure 4.

Mobility of capital is possible for Zannetos, because there are organized second hand and scrap markets. These markets stimulate competition and clear the freight market so that supply can equal demand. Successful shipping companies buy tonnage owned by bankrupt companies. But the capital loss that the first owner suffers-during a depression-is substantial. This was the case for the "very large and ultra large" tankers (VLCC; ULCC) involved in the two energy crises of 1973 and 1975, and for the more recent Hadjin bankrupt-case.

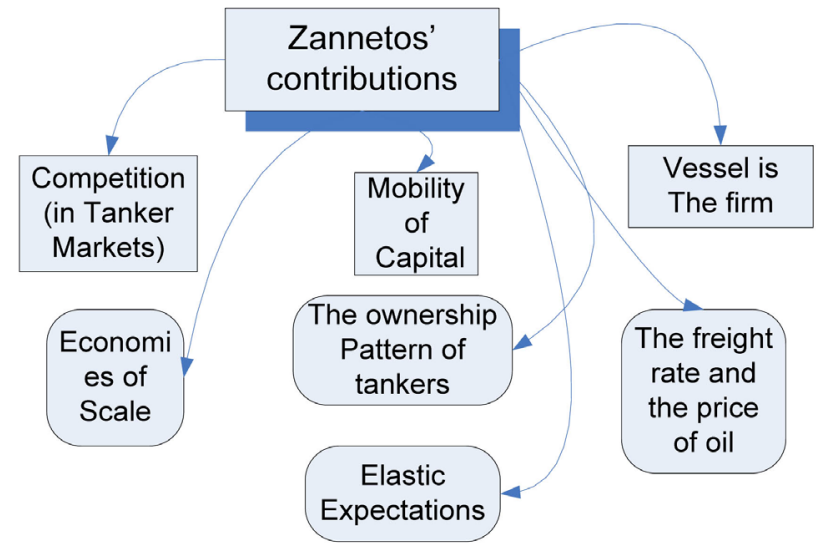

Figure 4. Zannetos' model applied to Tanker Economics, 1966. Source: Zannetos (1966) [4]; Veenstra and De La Fosse (2006) [7].

${ }^{24}$ Published by Lloyd's shipping economist. 
Zannetos was dissatisfied with the traditional static economic analysis, which, as Hicks noted, ignored time, and was unable to explain how tanker freight rates are formed. He was puzzled because freight rates and demand for tanker services were cyclical, while demand for oil was not...

Zannetos found his theoretical framework in Hicks' theory of expectations. His model is a product of his $\mathrm{PhD}$ thesis (1956-1959) at Massachusetts Institute of Technology. His book, based on it, was a continuation of the work of Koopmans (Zannetos, (1987) [57]). Hicks (1946) [58] argued that when elasticity of expectations is greater than unity, a change in current prices makes people feel that they can recognize a trend to extrapolate.

Zannetos argued that a substantial rate movement away from equilibrium creates expectations. More recent theory provides not one, but three main theories for expectations: adaptive, rational and behavioral. Because people anticipate the future and act on those assumptions, future freight rates will be proportionally greater or less than the current level. If this assumption is valid-which should be tested econometrically, using data provided by shipowners-then almost all Zannetos' theory follows. This could explain the cyclical behavior of markets, as expectations work as a stop-go mechanism. The elasticity of expectations is unity, and it is this elasticity that creates market instability. Moreover, new-building prices also move the system into market instability (Zannetos [4]; Dikos, (2004) [59]).

Georgantzi (2005) [60] found that the majority of people she interviewed in her MSc thesis considered that the parties involved in the chartering market for dry cargoes, are affected from $80 \%$ to $100 \%$, by forecasts future freight rates. This is of great importance, and should also be tested econometrically. There is a need for accurate forecasting in maritime businesses-an area where many maritime economists failed as have many ship owners.

Zannetos also recognized the term structure of freight rates in the long-run (Veenstra and De La Fosse, (2006) [7]). Short-run freight rates are formed by demand, influenced by freight rate expectations, and static supply. The longer run freight rate, he argued, is closer to equilibrium. As charter duration rises, freight rates approach long term equilibrium freight rate from above (in a boom) or from below (in a depression).

Figure 5 shows the impact of price elastic expectations, away from six equilibria, denoted by $R_{1}, R_{2}, R_{3}, R_{4}, R_{5}$ and $R_{s}$, between short and long run rates, whenever supply equals demand and when slopes are right for stability. Partial equilibria are also possible (Marshall, (1920) [61] in regions, $R_{2}$ (unstable) and $R_{3}$ (stable from below). $\mathrm{R}_{4}$ is unstable, and $\mathrm{R}_{5}$ is stable from above. Zannetos studied situations away ${ }^{25}$ from equilibrium, where there is a dynamic process moving towards equilibrium.

Zannetos argued that freight rates create a non-symmetrical behavior between buyers and sellers of ship space that is regular, non-uniform, and creates

${ }^{25}$ Prigogine (2003) [62] argued that non-equilibrium Physics gave him a better understanding of the mechanism of the emergence of the events. 


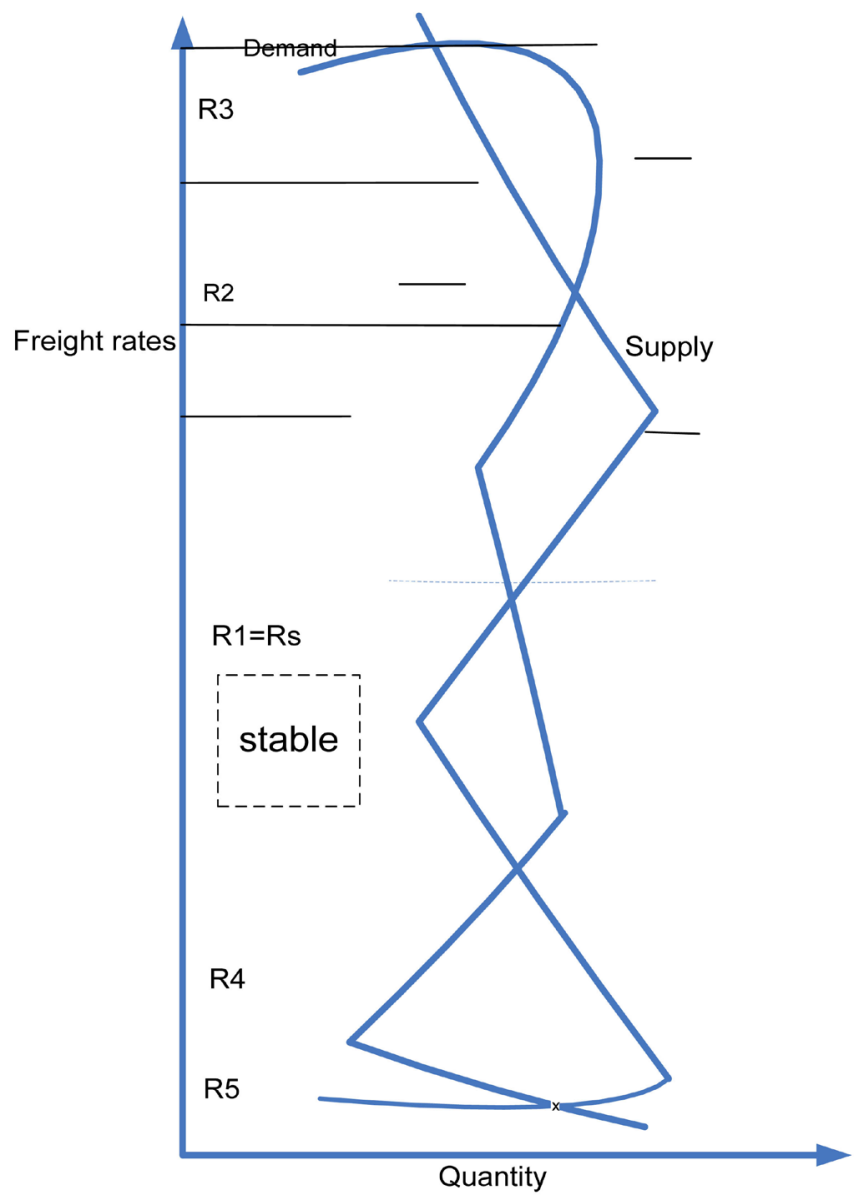

Figure 5. Freight rate determination by supply, demand and expectations of buyers and sellers of hiring a ship space. Source: Inspired by Zannetos (1966) [4].

alternating expectations. Buyers and sellers have no memory. Sellers react either immediately, or with a delay.

$$
Q=f(F)
$$

where $F$ stands for spot rates. Freight rates have long troughs and brief sudden peaks that can be simulated by an adapted cobweb model (Tvedt, (2003) [63]; Adland and Cullinane, forthcoming, [64]).

However, the above statement cannot be taken as always true, as for example, the 2003 to 2008 boom was not at all short. Zannetos assumed that expectations alternate between elastic and inelastic, if the market stays long enough at equilibrium. He made the peculiar statement that the memory of the market operators may not be long enough to recall how the market came to rest...

Zannetos discussed the pattern of ownership of the world tanker fleet meaning how much tonnage is (or should be) owned by the oil majors. He gave no consistent explanation of why oil majors kept a certain percentage, which was about 35\% of the world fleet (1950-1975), rising to about 40\% (1976-1985), and then falling to about 20\% (1986-2000) (Veenstra and De La Fosse, (2006) [7]). It finally dropped to below $10 \%$. 
We believe that the oil majors needed a specific percentage of ownership of the tanker fleet to control the market in an oligo-psonistic manner (1950-1985). Also, oil-majors induced independent owners to build new ships by negotiating with them long term (15 to 20 years) contracts at freight rates lower than the cost of their own ships (Goulielmos, (2013) [65], 2018 [52]). Independents were more competitive than oil companies, exploiting faster economies of scale and taking quicker decisions.

This policy, however, to increase existing supply (and removing a potential demand from the market), and in the end to lowering the freight rates to be paid by the oil majors, was brilliant. Oil majors have bureaucratic boards of directors. Some argue that the spot freight rate was the yardstick in negotiations. We believe that the oil majors' operating costs were the yardstick. Independents could not easily refuse a long term contract provided by a first class charterer that could be used in a bank to obtain finance for between $60 \%$ and $80 \%$ to build the ship involved. Independents relied on profit from their lower operating costs and economies of scale building larger ships than had previously in the market (e.g. Onassis, Niarchos).

Strandenes (2012) [66] argued that Zannetos conceived the shape of the supply curve empirically, and added expectations to explain cycles in freight rates. For Zannetos cycles is inherent in shipping. Koopmans [3] explained, wrongly, that the shipping cycle is due to the replacement of ships, which did not satisfy Zannetos-quite rightly. Greek shipping companies, when there are rock bottom ship prices, buy ships, adding to their fleets larger and younger ships (a strategy $=$ of firm growth). Also, they buy used ships that are about five years old, of new types (diversification; product carriers; VLCC).

Glen and Martin (1998) [67] argued that Zannetos developed a formal explanation forthe spot freight rate to converge (from above or below) to the long run marginal cost of the vessel, using a "bareboat" ${ }^{26}$ charter as a proxy.

\section{The Norwegian Center, 1976-1985}

Eriksen and Norman (1976) [68] related ship values to tanker freight rates. Eriksen (1977) [69] was the first to deal with the estimation of demand (dry cargo). He concluded that high freight rates lead (charterers) to shorter distances, which was later confirmed by Evans, (1994) [49], on experience from Suez Canal closures.

$$
\begin{aligned}
& \text { Wergeland (1981) [70] defined } \\
& \qquad \begin{array}{l}
\text { supply(in ton-miles) as }=T^{d} F^{-e}
\end{array}
\end{aligned}
$$

where $T$ is world's bulk trade, and $e$ is assumed positive; $d$ is roughly unity. Wergeland used the methods: two stages least squares, full information maximum likelihood and a log-linear approach. He proved that the existence of laid-up tonnage determines elasticity of supply, something argued also by

\footnotetext{
${ }^{26}$ The ship is capable, but not ready, to transport cargo. It is a bare... ship.
} 
Koopmans [3]. Norman and Wergeland (1981) [71] optimized vessels' speed to find freight rates, using a solvable (analytical) model.

Strandenes (1981) [72] estimated the cross effects in tankers of different ship sizes. She used the model [74] of a perfectly competitive market and assumed equilibrium between supply and demand in short- and long-term time-charters. She assumed market efficiency. Combined carriers taken as exogenous in her model simulated the possible interdependencies between tanker and dry cargo freight markets. She specified size groups taking care of port limitations for larger vessels, like ULCCs. She simulated the effects on freight rate and profitability of oil price shocks, including slow-steaming. Strandenes and Wergeland (1981) [73] related the ship values to freight rates of tankers, and to shipbuilding and scrapping.

Strandenes (1984) [74] modeled time charter rates:

$$
T C=r(t)\left[a p+b p^{*}\right]
$$

where $T C=$ time charter, valid today with duration $t, p=$ current time charter equivalent in the short-term, $p^{*}=$ expected long term time charter equivalent and $r(t)=$ risk premium in the short and long run. She worked on bulk carriers, medium sized tankers and large tankers, including expectations. If $r(t)<1$, owners accept a lower $p$, if a time charter is safer than a (riskier) spot market. A drop in fuel cost, significantly and permanently, reduces freight rates by increasing distances, and S, given the existence of "combined carriers" 27 .

Profitability depends on elasticity of demand and fuel costs. Inperfectly competitive markets, where demand equals supply, then

$$
T=P(r+d)-O C
$$

where $r=$ the return on capital, $T=$ long term TCE (time charter equivalent), $O C=$ long term operating costs; and $P=$ the new-building price; OLS are used. She estimated a set of parameters for the term structure of freight rates. Beenstock (1985) [75] examined the formation of ship prices. He triggered a number of studies (Vergottis, (1988) [11]; Hale and Vanags, (1992) [41]; and Glen, (1997) [76]).

Strandenes (1986) [77] used a present value model with semi-rational expectations (1968-1981) (annual) and rational expectations. She assumed that ship prices are determined by current market rates and long-run equilibrium rates, derived from the replacement value and economic life of vessels, and an attainable rate of return. She accepted that the market is efficient, following Fama's (1964) [78] doctoral thesis. The present value of a time charter should be equal to the expected present value of the TCE, including risk. TCE equals spot market profit plus fixed operating costs.

This means that in order for a market to be efficient, all relevant information has to have been included in the price. But the hypothesis that the market is efficient has been disputed for some time, especially after 1987 (Black Monday).

${ }^{27}$ Transporting more than one type of cargos. 
Strandenes (1990) [79] examined the effects of the problem of capacity utilization shipbuilding and shipping in 1990s.

\section{The "Beenstock-Vergottis" Model and the English Center, 1986-1995}

This period is characterized by the work of Beenstock and Vergottis (1989 a, b) [80] [81], 1993 [5] and 1995 [82]). Hawdon (1978) [83] modeled supply and demand, the fleet, fuel price, and: the price of new-buildings, wages of seamen, average size of ships, freight rates of dry cargo ships (in grain transport) and some dummies variables. He found the latter not to be statistically significant for freight rates estimation, using a reduced form regression in long and shortrun. He also estimated the cross effects of spot freight rates between tankers and dry cargoes (1953-1973). He found no evidence for the impact of combined carri$\mathrm{ers}^{28}$.

Maritime economists at this time were heavily preoccupied with the cross effects of spot freight rates between tankers and dry bulks, due to the appearance of combination carriers. These ships, initially called OBO (oil-bulk-ore), of a total of 49m dwt globally, had handsome profits between 1967 and 1970 and in 1973. Stopford (2009) [14] million mentioned a $\$ 2000$ to $\$ 3000$ revenue premium per day. Initially, maritime economists used short-run models.

Charemza and Gronicki (1981) [84] argued that demand is completely insensitive to freight rates ${ }^{29}$. They created a linear bulk market model with freight rates in disequilibrium, supply and demand taken at their minima, and freight rates changed proportionally to excess demand. Their econometric models were separate for dry bulk and tankers, where ship values made it possible to react to changes in freight rates. Beenstock (1985) [75] proposed a dynamic general equilibrium model to determine ship prices given current and expected freight rates, assuming market efficiency, rational expectations and an index for global economic activity. He used a present value model.

Hale and Vanags (1989) [85] examined spot and period bulk freight rates modeling risk aversion, or liquidity preference (i.e. to be in the spot market). They performed several tests for market efficiency of shipping freight rates using single equation regression. They found no evidence of term structure between freight rates. Glen (1990) [86] dealt with the relationship between risk and ship size (annually). He found that volatility, i.e. the variation of estimated gross profit margins, systematically increased with size (except on the Caribbean-US Gulf route) $)^{30}$.

Hale and Vanags (1992) [41] examined the efficiency, (in its weak form in the sense of 1970 Fama, so that historical share prices cannot be used, of the second ${ }^{28} \mathrm{~A}$ new type of ships emerged at the beginning of $1960 \mathrm{~s}$.

${ }^{29}$ If the \% of $\mathrm{F}$ in CIF price is low; if $\mathrm{F}$ is substantial, it affects CIF price and thus demand! This has been proved when the oil of price increased substantially, the demand of oil fell. Economists committed the erroneous assumption of a very inelastic demand for oil!

${ }^{30} \mathrm{He}$ admitted that Glen and Martin's (1998) [67] model, used short data of only 9 years was also naive. 
hand ship market using co-integration and Granger causality between three time series. They found evidence of co-integration in dry bulks, meaning market inefficiency. They next focused on the stochastic nature of and the relationship between changes of second hand prices of Handy, Panamax and Cape (monthly: 10/1979-07/1988). All variables were integrated of order 1, meaning a random walk. Their results were inconclusive. Wright (1993) [87] assessed expectations in shipping by comparing estimates of rational expectations with stable expectations, and also adaptive expectations. His findings were inconclusive.

Campbell and Shiller (1991) [88], in a seminal paper, introduced a single linear expectations theory of term structure of interest rates. There is, however, no overall consensus so far among econometricians about the expectations hypothesis of the term structure of interest rates (Brooks, 2014) [26]). He [87] used empirical evidence of the variations in the prices of second hand ships to test both rational and non-rational expectations.

He found no clear grounds on which to reject them. So, ship-owners may well employ both rational and non-rational expectations, depending on market conditions. He said that the key factor is the level of confidence in rational expectations. He examined the nature of expectations in the market for secondhand ships, but there were no obvious grounds for distinguishing between them.

Beenstock and Vergottis (1993) [5] used micro foundations in deriving demand and supply, putting extra emphasis on combination (Combi) new buildings. They argued that

$$
R=F * s
$$

where $R$ is the freight revenue per unit of time period, $F$ in $\$$ per-ton mile, and $s$ $=$ speed in milesper unit time period.

$$
b=s^{\alpha}
$$

where $b=$ bunker (fuel) consumption in tons and $\alpha$ is a technology constant coefficient, assumed to be greater than unity (=decreasing returns to scale). A more interesting case that has been totally neglected by economists is where there are increasing returns to scale (Goulielmos, (2018), [89]).

They argued [5] that the assumption of $\alpha>1$ is theoretically necessary for maximization.

$$
\text { Profits }=\Pi=F s-P b-O C
$$

where $P$ is the price of fuel, $O C$ fixed costs (operating). Now

$$
T C E=\Pi+O C=F s-P b
$$

and given that $\mathrm{b}$ is a function of speed (15) becomes

$$
\Pi=F s-P s^{\alpha}-O C
$$

Profit maximization of the vessel requires:

$$
\begin{gathered}
\mathrm{d} \Pi / \mathrm{d} s=F-\alpha P s^{\alpha-1}=0 \\
s=(F / \alpha P)^{1 /(\alpha-1)}=\text { optimum speed }
\end{gathered}
$$


To maximize profits, speed must vary with the ratio of freight rate to fuel price.

Equation (17) implies that maximum profit is related to freight rates and fuel prices. Following certain further steps-omitted here-they can determine total market supply. Next, demand is assumed exogenous and completely inelastic. For market equilibrium,

$$
D=K(F / \alpha P)^{1 /(\alpha-1)}
$$

where $K$ = carrying capacity in dwt of all ships. No data could be found on profits or expected profits.

They used 2SLS (equivalent to 3SLS), OLS, instrumental variables in place of 2SLS (where the full economic structural system of equations could be used), simulation, with an emphasis on rational expectations, 3SLS (better is the generalized method of moments-GMM, 1982, also in 3 stages), using optimization (maximizing profits), and perfect competition (in a structural model).

Expectations are formed in the most effective way through an information mechanism so that forecasting error is random and unforeseen. Rational expectations are the result of rational maximizing behavior in acquiring and processing information to form a view about the future. They also modeled the interdependencies between dry cargo and tanker markets and the market for ships and rational expectations.

Papadopoulos and Tamvakis (1994) [90] used probability theory in investment decision-making and simulation, with a Monte Carlo method overcoming a number of problems. Forecasting using simulation is usually inaccurate. The $\chi^{2}$ method, however, was found to be more appropriate.

Evans (1994) [49] modeled revenue per ship mile:

$$
3 p k s^{2}=M C
$$

where $F=$ freight rate, $M C=$ marginal cost, $p=$ price of fuel with a constant $k, s$ = optimum speed/miles per day (the time spent in ports is ignored), plus profit maximization. $F=M C ; M C=$ Marginal Revenue = Average Revenue. He argued that in the long-run supply does not equal demand. $M C=$ the cost of producing for an additional ship-mile.

$$
M C \text { per ship mile }=3 p k s o^{2}+2 p k s o^{3} t / d
$$

where $s$ is the optimum speed and $s^{\star} o$ is the voyage speed, $k$ is a constant, $d$ is distance, $p$ is the price of fuel, and $t$ is voyage time. If $t=0$, revenue per ship mile $=3 p k s^{2}$.

Glen (1991) [91] reviewed Evans and Marlow's (1990) book [92], and argued that the latter ignored the steady increase in the number of shipping econometric models over the period from 1980 to 1990, while they used difference equations and modeled expectations.

\section{A Critique of Models Presented}

Most of maritime papers reviewed above reached contradictory findings and ul- 
timately were inconclusive. All shipping firms in the market assumed theoretically, at equilibrium, that their ships were ready to supply services in a process of profit maximization. But in practice a shipping company tries to negotiate, using in-house, or appointing brokers, with the brokers of charterers, for a freight rate using the market for previous similar and recent charters as a benchmark. Firms try to achieve this pre-determined freight rate in a process of constrained maximization. This conforms to a shortrun purely competitive market.

Moreover, shipping markets are assumed to clear instantaneously, which is not true. A shipping market may need years to clear, (e.g. the tanker market in the 1970s). McConville (1998; editorial) [93], argued in response to the 1973 crisis: "The presumption of shipping market equilibrium, or movements towards that, was severely undermined, as was an acceptance of the concomitant concept of market clearance... The notion of the classical economists of market equilibrium began to be questioned particularly at the microeconomic level. For the obvious fact that shipping market did not clear. Inherent over-capacity of ships, being large individual capital investments, did not clear the market in the immediate short- or extremely long-run.

In Tinbergen's model [15] no degree of goodness of fit was mentioned (e.g. $\mathrm{R}^{2}$ with no intercept). No error term appeared; his equation was exact. Koopmans (1939) [3] argued that expectations about future returns do not influence investment decisions, contrary to the opinion of Keynes and almost all economists. In addition, there are many definitions of maritime marginal cost, indicating an apparent weakness of theory in providing a unique definition.

Zannetos (1966) [4] implicitly recognized the long-range dependence in his time series for rates (1949-1958), where the past continued to influence random fluctuations in the present (Mandelbrot and Hudson, (2006/8) [24], in another context). He argued that, "The quantitative exactness of regression models is not always reliable" (p. 232). The spot freight rate is not the only factor that influences investing in a new building (Goulielmos, (2014) [50]).

Importantly, Zannetos argued that a random walk was not present in his empirical findings, but if it was, it would negate the theory of price elastic expectations... Zannetos argued that the probability that one positive change would be followed by another positive change is high, i.e. 61\% (Lyridis and Zacharioudakis, (2012) [94], confirmed this). Goulielmos demonstrated (1974) [95] that if the firm is the vessel, then average and marginal cost curves will be different from those supported by economic theory.

Eriksen (1977) [69] modeled more than one shipping market, also using maximization. This was progress, and a departure from single demand and supply models. He examined all four shipping markets (the freight rate market, second hand, new-buildings and scrapping). Hawdon (1978) [83] was the first victim of simultaneity, as he estimated demand by trying to estimate supply, using a simulation model. 
Owners order ships if trade increases, freight rates rise, and prices (of new buildings) fall. Also, the price of steel can be inserted into the regression of freight rates (both affecting new building prices). Orders affect deliveries (positively). Scrapping depends on expected future profits of old ships and on the size of the fleet (supply). Freight rates and demand affect (negatively) scrapping (if high). The fleet size is the supply, and the fleet grows when there are new deliveries and shrinks when vessels are scrapped.

Wergeland (1981) [70] failed to estimate correctly the fleet size coefficient in the supply function, because his demand data was incompatible with that of the fleet. He adjusted a coefficient, in a simulation model, arbitrarily, to unity 1, and he assumed the elasticity of demand with respect to freight rates to be -0.4 , in order to get better results. Supply was influenced by lay-up. Strandenes (1984) [74] argued that prices are more affected by changes in the long-term equilibrium profits than changes in current profits. This conclusion was different from her previous findings, but was similar in that of Keynes in his General Theory etc. book.

Hale and Vanags (1992) [41] rejected the hypothgesis that market is efficient, contrary to the findings of Beenstock (1985) [75] and Strandenes (1986) [77]. This is also a serious blow to perfect competition. The data in Beenstock and Vergottis' work (1993) [5] was found to have certain problems, and their book lacked further editing [96]. Eales (1995 book review) [96] suggested the use of neural networks. Such a model appeared by Li and Parsons two years later (1997) [97].

\section{Suggestions for Further Shipping Econometric Research}

Three essential claims about market behavior derive from the above assumptions, and these need to be carefully evaluated: 1) the best estimate of tomorrow's freight rate is today's; 2) tomorrow's freight rate is independent of past freight rates; 3) changes in freight rate vary in accordance with a normal distribution. The assumption of efficient markets implies that asset prices will rapidly reflect all relevant and available information though the exact speed required has not been specified.

\subsection{Unit of Analysis: Vessel or Firm}

A mistake committed by Thorburn (1960; p. 11) [51]) was to argue that the vessel was the unit on which his investigation should be based, and that in tramp $p^{31}$ shipping, the vessel forms the economic unit of analysis (i.e. the shipping company), while the shipping company per se plays a subordinate role. This approach, though wrong especially after 1960, was also adopted by Zannetos [4] (for a detailed analysis about this serious mistake see Goulielmos, (2018) [52].

\subsection{Shipping Marginal Cost}

Metaxas (1971) [53] defined marginal cost as that of around voyage. Marginal

${ }^{31}$ Ships with varying pair of ports each time as mentioned. 
cost is better thought of as the addition to total cost of the vessel for a one way voyage. Metaxas however, was known for his contribution to social costs in shipping and his accurate knowledge of operating costs.

\subsection{Other Important Maritime Economists}

Professor Heaver (1993) [54]; 2012) [55]) considered the books of Zannetos (1966) [4] and Shimojo (1979) [56] to be the best two analytic books. Shimojo presented the way freight rates are determined in tramp shipping, showing time in a third axis. Goss was the founder of maritime economics in UK (Goulielmos, (2018) [52]). Svendsen was the first to write a good mathematical shipping economics textbook in 1958. Georgandopoulos published a shipping textbook in 1953 (in Greek) and he organized the first international conference of maritime economists in 1976 in Piraeus [55].

\subsection{Further Questions}

It is important to know whether elastic expectations really apply to shipping, and whether perfect competition occurs in the bulk and tanker industries (Goulielmos, (2013) [65], (2018) [52]. There is also the problem as to whether (and when) spot or time charter freight rate are more decisive in a variety of ship owners' decisions.

Moreover, free-exit from the market is not as free as certain maritime economists believe (the Hajin case). It is also worth re-examining the concept of the shortrun in shipping. A shipping company almost always makes decisions in the shortrun as most decisions of a shipping firm to change the level of the firm's capital, or number of ships need no more than one to two months.

Depressions had the magic to force all kinds of models, including econometric models to fail (Weatherall, (2013) [98]). To date, models have shown themselves to be useful for peace (no depressions), but unsuitable for the "war". As Qin (2013) [22] argued, ex-ante forecasts of recessionary downturns remain disappointing. The period of energy crises proved that the statistical tools used during "peace" fail during "war", including the widely celebrated tool of the normal distribution (Goulielmos and Psifia, (2011) [99]; Weatherall, (2013) [98]; Buchanan, (2013) [100]).

The most crucial trigger for econometrics was the widespread failure of macro-econometric models to predict global recession after the 1973 oil crisis. Macro-econometric models also failed to predict the depression at the end of-2008 (Lucas and Sargent, (1979) [101]; Lucas, (1976) [102]).

A new feature has now arisen with the appearance of futures markets. It needs to be investigated whether the parties involved in a chartering market for dry cargos and tankers are substantially affected by futures forecasts. Above all it is important to understand the influence of future freight rates agreements (FFAs).

The concept of the shortrun in shipping needs to be re-examined, as mentioned. For the industry, shortrun is when new ships cannot be built. This time 
can be from one to four years. For the firm, shortrun is when additional ships cannot be bought. This time is from one to two months.

\section{Conflicts of Interest}

The author declares no conflicts of interest regarding the publication of this paper.

\section{References}

[1] Intriligator, M. (1978) Econometric Models: Techniques and Applications. Prentice Hall, USA.

[2] Smith, A. (1776) An Inquiry for the Nature and the Causes of the Wealth of Nations. Greek Translation, Newspaper "Vima".

[3] Koopmans, T.C. (1939) Tanker Freight Rates and Tankship Building, Haarlem.

[4] Zannetos, Z.S. (1966) The Theory of Oil Tankship Rates. MIT Press, Cambridge.

[5] Beenstock, M. and Vergottis, A. (1993) Econometric Modeling of World Shipping. Chapman \& Hall, London.

[6] Kavussanos, M.G. (1996) Comparisons of Volatility in the Dry-Cargo Ship Sector. Spot versus Time-Charters and Smaller versus Larger Vessels. Transport Economics \& Policy, 30, 67-82.

[7] Veenstra, A.W. and De La Fosse, S. (2006) Contributions to Maritime EconomicsZenon S. Zannetos, the Theory of Oil Tankship Rates. Maritime Policy \& Management, 33, 61-73. https://doi.org/10.1080/03088830500513444

[8] Talley, W.K. (2012) General Introduction, the Blackwell Companion to Maritime Economics. Wiley-Blackwell, Oxford, 3-15.

[9] Goulielmos, A.M. (2002) Complexity Theory Applied to Management of Shipping Companies. Maritime Policy \& Management, 29, 375-391. https://doi.org/10.1080/03088830210144305

[10] Glen, D. (1987) Differentiation in the Oil Tanker Market. PhD Thesis, University of London, London.

[11] Vergottis, A. (1988) An Econometric Model of World Shipping. PhD Thesis, City University Business School, London.

[12] Kavussanos, M.G. (1992) An Empirical Examination of Bilateral Seaborne Trade Flows in the World Economy. PhD Thesis, City University Business School, London.

[13] Psifia, E.-M. (2006) A Critical Analysis of Traditional Methods of Financing Shipping Investments and Proposals for Innovation. Ph.D. Thesis, University of Piraeus, Piraeus.

[14] Stopford, M. (2009) Maritime Economics. 3rd Edition, Rutledge, London. https://doi.org/10.4324/9780203891742

[15] Tinbergen, J. (1959) (1) (1934): “Scheepsruimte en vrachten" and (2) (1931): "Ein Schiffbauzyclus?” De Nederlandsche Conjunctuur, March: 23-35. In: Klassen, J.C., Koyck, L.M. and Wittenveen, H.J., Eds., Jan Tinbergen: Selected Papers, North Holland, Haarlem.

[16] Goulielmos, A.M. (2018) Maritime Econometrics: Models of Dry Cargo Ships and Tankers, 1996-2005 Survey. Modern Economy, 9, 12.

https://doi.org/10.4236/me.2018.912136 
[17] Goulielmos, A.M. (2018) Maritime Economic Modeling: A Survey, 2006-2016. Modern Economy, 9, 12. https://doi.org/10.4236/me.2018.912129

[18] Galton, F. (1885) Presidential Address to a (Not Specified) Society. Physical Inheritance (1889), London.

[19] Frisch, R. (1938) Autonomy of Economic Relations: Statistical versus Theoretical Relations in Economic Macro-Dynamics, in the Foundations of Econometric Analysis. Cambridge University Press, London, 407-424.

[20] Haavelmo, T. (1943) The Statistical Implications of a System of Simultaneous Equations. Econometrica, 11, 1-12. https://doi.org/10.2307/1905714

[21] Haavelmo, T, (1944) The Probability Approach in Econometrics. Econometrica, 12, 12-17. https://doi.org/10.2307/1906935

[22] Qin, D. (2013) A History of Econometrics. Oxford U P, Oxford. https://doi.org/10.1093/acprof:oso/9780199679348.001.0001

[23] Cowles, A. (1933) Can Stock Market Forecasters Forecast? Econometrica, 1, 309-324. https://doi.org/10.2307/1907042

[24] Mandelbrot, B.B. and Hudson, R.L. (2006/2008) The (mis)behavior of Markets: A Fractal View of Financial Turbulence. Basic Books, New York.

[25] Heckman, J.J. (2000) Causal Parameters and Policy Analysis in Economics: A 20th Century Retrospective. Quarterly of Economics, 115, 45-97. https://doi.org/10.1162/003355300554674

[26] Brooks, C. (2014) Introductory Econometrics for Finance. $3^{\text {rd }}$ Edition, Cambridge University Press, Cambridge. https://doi.org/10.1017/CBO9781139540872

[27] Marschak, J. (1946) Quantitative Studies in Economic Behavior. Report to Rockefeller Foundation.

[28] Epstein, R. (1987) A History of Econometrics, Amsterdam, North-Holland.

[29] Epstein, R. (1989) The Fail of OLS in Structural Estimation. Oxford Economic Papers, 41, 94-107. https://doi.org/10.1093/oxfordjournals.oep.a041930

[30] Sims, C.A. (1980) Macroeconomics and Reality. Econometrica, 48, 1-48. https://doi.org/10.2307/1912017

[31] Hendry, D.F. (1980) Econometrics: Alchemy or Science? Economica, 47, 387-406. https://doi.org/10.2307/2553385

[32] Theil, H. (1953) Estimation and Simultaneous Correlation in Complete Equation Systems. The Hague: Central Planning Office (Mimeo).

[33] Basmann, R. (1957) A Generalized Classical Method of Linear Estimation of Coefficients in a Structural Equation. Econometrica, 25, 77-83. https://doi.org/10.2307/1907743

[34] Sargan, D. (1958) The Estimation of Economic Relationships Using Instrumental Variables. Econometrica, 26, 393-415. https://doi.org/10.2307/1907619

[35] Sargan, D. (1959) The Estimation of Relationships with Autocorellated Residuals by the Use of Instrumental Variables. Royal Statistical Society, Series B, 21, 91-105.

[36] Zellner, A. (1962) An Efficient Method of Estimating Seemingly Unrelated Regressions and Tests for Aggregation Bias. American Statistical Association, 57, 348-368. https://doi.org/10.1080/01621459.1962.10480664

[37] Phillips, P.C.B. (1986) Understanding Spurious Regressions in Econometrics. Econometrics, 33, 311-340. https://doi.org/10.1016/0304-4076(86)90001-1

[38] Engle, R. and Granger, C. (1987) Co-Integration and Error-Correction: Representation Estimation and Testing. Econometrica, 55, 251-276. 
https://doi.org/10.2307/1913236

[39] Kavussanos, M.G. and Alizadeh, A.H. (2002) Efficient Pricing of Ships in the Dry Bulk Sector of the Shipping Industry. Maritime Policy \& Management, 29, 303-330. https://doi.org/10.1080/03088830210132588

[40] Kavussanos, M.G. and Alizadeh, A.H. (2002) The Expectations Hypothesis of the Term Structure and Risk Premiums of Dry Bulk Shipping Freight Markets. Transport Economics \& Policy, 36, 267-304.

[41] Hale, C. and Vanags, A. (1992) The Market for Second-Hand Ships: Some Results on Efficiency Using Co-Integration. Maritime Policy \& Management, 19, 31-40. https://doi.org/10.1080/03088839200000003

[42] Campbell, J.Y. and Shiller, R.J. (1987) Co-Integration and Test of Present Value Models. Political Economy, 95, 1062-1088. https://doi.org/10.1086/261502

[43] Engle, R.E., Lilien, D.M. and Robins, R.P. (1987) Estimating Time-Varying Risk Premia in the Term Structure: The ARCH-M Model. Econometrica, 55, 391-407. https://doi.org/10.2307/1913242

[44] Goulielmos, A.M. (2009) Risk Analysis of the Aframax Freight Market and of Its New Building and Second Hand Prices, 1976-2008 and 1984-2008. Shipping \& Transport Logistics, 1, 74-97. https://doi.org/10.1504/IJSTL.2009.021977

[45] Box, G.E.P. and Jenkins, G.M. (1976) Time Series Analysis: Forecasting and Control. $2^{\text {nd }}$ Edition, Holden-Day, S. Francisco.

[46] Schweitzer, F. (2002) Modeling Complexity in Economic and Social Systems. World Scientific, Singapore.

[47] Estola, M. (2002) A Dynamic Theory of a Firm: An Application of Economic Forces. In: Schweitzer, F., Ed., Modeling Complexity in Economic and Social Systems, World Scientific Publishing, Mainland Press, Singapore, Chapter 13.

[48] Peters, E.E. (1996) Chaos and Order in the Capital Market: A New View of Cycles, Prices, and Market Volatility. ${ }^{\text {nd }}$ Edition, a Wiley Finance Edition.

[49] Evans, J.J. (1994) An Analysis of (the) Efficiency of the Bulk Shipping Markets. Maritime Policy \& Management, 21, 311-329.

https://doi.org/10.1080/03088839400000055

[50] Goulielmos, A.M. (2014) Why Shipowners Place Excessive Orders during a Depression? Social Science Research, 2.

[51] Thorburn, T. (1960) Supply and Demand of Water Transport: Studies in Cost and Revenue, Structure of Ships, Ports and Transport Buyers with Respect to Their Effects on Supply and Demand of Water Transport of Goods. The Business Research Institute of the Stockholm School of Economics.

[52] Goulielmos, A.M. (2018) The Unresolved Issues in Maritime Economics. Modern Economy, 9, 1687-1715.

[53] Metaxas, B.N. (1971) The Economics of Tramp Shipping. Athlone Press, London.

[54] Heaver, T.D. (1993) The Many Facets of Maritime Economics in Association. Maritime Policy \& Management, 20, 121-132. https://doi.org/10.1080/03088839300000023

[55] Heaver, T.D. (2012) The Evolution of Maritime Economics. In: Talley, W.K., Ed., The Blackwell Companion to Maritime Economics, Wiley-Blackwell, Oxford, 16-33.

[56] Shimojo, T. (1979) Economic Analysis of Shipping Freights. Research Institute for Economic and Business Administration, Kobe University, Kobe.

[57] Zannetos, Z.S. (1987) Oil Tanker Markets: Continuity amidst Change. In: Gordon, 
R., Jacoby, H. and Zimmerman, M., Eds., Energy, Markets and Regulation, MIT Press, London, 235-257.

[58] Hicks, J.R. (1946) Value and Capital: An Inquiry into Some Fundamental Principles of Economic Theory. $2^{\text {nd }}$ Edition, Clarendon Press, Oxford.

[59] Dikos, G. (2004) New-Building Prices: Demand Inelastic or Perfectly Competitive. Maritime Economics \& Logistics, 6, 312-321. https://doi.org/10.1057/palgrave.mel.9100115

[60] Georgantzi, A. (2005) A Review of the Proportion of Voyage against Time Charter Fixtures at Various Phases of the Freight Market. MSc Thesis, City University.

[61] Marshall, A. (1920) Principles of Economics. $8^{\text {th }}$ Edition, Macmillan \& Co. Ltd., London.

[62] Prigogine, I. (2003) Is Future Given? World Scientific, Singapore. https://doi.org/10.1142/5352

[63] Tvedt, J. (2003) A New Perspective on Price Dynamics of the Dry Bulk Market. Maritime Policy \& Management, 30, 221-230. https://doi.org/10.1080/0308883032000133413

[64] Adland, R. and Cullinane, K. (2006) The Non-Linear Dynamics of Spot Freight Rates in Tanker Markets. Transportation Research Part E: Logistics and Transportation Review, 42, 211-224.

[65] Goulielmos, A.M. (2013) Oil Transport Management, Shipping and Transport Logistics. Collection of Papers, Springer-Verlag, London, 27-62.

[66] Strandenes, S.P. (2012) Maritime Freight Markets. In: Talley, W.K., Ed., The Blackwell Companion to Maritime Economics, Wiley-Blackwell, Oxford, 107-120.

[67] Glen, D.R. and Martin, B.T. (1998) Conditional Modeling of Tanker Market Risk Using Route Specific Freight Rates. Maritime Policy \& Management, 25, 117-128. https://doi.org/10.1080/03088839800000023

[68] Eriksen, I.E. and Norman, V.D. (1976) Ecotank: Econometric Model for Tanker Companies. ISR, NSEBA, Bergen. (In Norwegian)

[69] Eriksen, I.E. (1977) The Demand for Bulk Ship Services. Norwegian Maritime Research, 2, 22-26.

[70] Wergeland, T. (1981) Norbulk: A Simulation Model of Bulk Freight Rates. WP 12, Norwegian School of Economic and Business Administration, Bergen.

[71] Norman, V.D. and Wergeland, T. (1981) Nortank: A Simulation Model of the Freight Market for Large Tankers. R 4, CAR, NSEBA, Bergen.

[72] Strandenes, S.P. (1981) Demand Substitution between Tankers of Different Sizes. Studies in Shipping Economics, Hope, Oslo, 63-77.

[73] Strandenes, S.P. and Wergeland, T. (1981) Ecotank-An Updated Version. Bergen.

[74] Strandenes, S.P. (1984) Price Determination in the Time Charter and Second Hand Markets. Norwegian School of Economics and Business Administration, Bergen, 584.

[75] Beenstock, M. (1985) A Theory of Ship Prices. Maritime Policy \& Management, 12, 215-225. https://doi.org/10.1080/03088838500000028

[76] Glen, D.R. (1997) The Market of 2nd-Hand Ships: Further Results on Efficiency Using Co-Integration Analysis. Maritime Policy \& Management, 24, 245-260. https://doi.org/10.1080/03088839700000029

[77] Strandenes, S.P. (1986) Norship: A Simulation Model of Markets in Bulk Shipping. Norwegian School of Economics \& Business Administration, Bergen, 11. 
[78] Fama, E.F. (1964) The Distribution of Daily Differences of Stock Prices: A Test of Mandelbrot's Stable Paretian Hypothesis. PhD, University of Chicago Graduate School of Business.

[79] Strandenes, S.P. (1990) Capacity Utilization in Shipbuilding and Shipping, Shipping Strategies and Bulk Shipping in the 1990s. Strandenes-Svendsen and Wergeland, Bergen.

[80] Beenstock, M. and Vergottis, A. (1989a) An Econometric Model of the World Market for Dry Cargo Freight and Shipping. Applied Economics, 21, 339-356. https://doi.org/10.1080/758522551

[81] Beenstock, M. and Vergottis, A. (1989b) An Econometric Model of the World Tanker Market. Transport Economics \& Policy, 23, 263-280.

[82] Beenstock, M. and Vergottis, A. (1993) The Interdependence between the Dry Cargo and Tanker Markets. Transportation \& Logistics Review, 29, 3-38.

[83] Hawdon, D. (1978) Tanker Freight Rates in the Short and Long Run. Applied Economics, 10, 203-217. https://doi.org/10.1080/758527274

[84] Charemza, W. and Gronicki, M. (1981) An Econometric Model of World Shipping and Shipbuilding. Maritime Policy \& Management, 21-30. https://doi.org/10.1080/03088838100000019

[85] Hale, C. and Vanags, A. (1989) Spot and Period Rates in the Bulk Market. Transport Economics \& Policy, 23, 281-291.

[86] Glen, D.R. (1990) The Emergence of Differentiation in the Oil Tanker Market, 1970-78. Maritime Policy \& Management, 17, 289-312. https://doi.org/10.1080/03088839000000034

[87] Wright, G. (1993) Expectations in the Shipping Sector. Transport Economics, 20, 67-76.

[88] Campbell, J.Y. and Shiller, R.J. (1991) Yield Spreads and Interest Rate Movements: A Bird's Eye View. Review of Economic Studies, 58, 495-514. https://doi.org/10.2307/2298008

[89] Goulielmos, A.M. (2018) Self-Reinforcing Mechanisms in Economics: With Two Case-Studies from Shipping Industry. Modern Economy, 9, 7. https://doi.org/10.4236/me.2018.97085

[90] Papadopoulos, P.A. and Tamvakis, M.N. (1994) Applications of Probability Theory to Marine Project Appraisal. Maritime Policy \& Management, 21, 103-123. https://doi.org/10.1080/03088839400000028

[91] Glen, D.R. (1991) Quantitative Methods in Maritime Economics, a Book Written by Evans and Marlow in 1990. Maritime Policy \& Management, 18, 146. https://doi.org/10.1080/03088839100000042

[92] Evans, J.J. and Marlow, P.B. (1990) Quantitative Methods in Maritime Economics. $2^{\text {nd }}$ Edition, Fairplay Publs, London.

[93] McConville, J. (1998) 25 Years on. Maritime Policy \& Management, 25, 1-2. https://doi.org/10.1080/03088839800000041

[94] Lyridis, D. and Zacharioudakis, P. (2012) Liquid Bulk Shipping. In: Talley, W.K. Ed., The Blackwell Companion to Maritime Economics, Wiley-Blackwell, Oxford, 205-229. https://doi.org/10.1002/9781444345667.ch11

[95] Goulielmos, A.M. (1974) A Vintage Model Approach to Some Problems of Shipping Economics. Unpublished PhD Thesis, Brunel University.

[96] Eales (1995) Book Reviews. Maritime Policy \& Management, 22, 95-96. 
https://doi.org/10.1080/03088839500000036

[97] Li, J. and Parsons, M.G. (1997) Forecasting Tanker Freight Rate Using Neural Networks. Maritime Policy \& Management, 24, 9-30. https://doi.org/10.1080/03088839700000053

[98] Weatherall, J.O. (2013) The Physics of Wall Street, a Brief History of Predicting the Unpredictable. Houghton Mifflin Harcourt, Boston.

[99] Goulielmos, A.M. and Psifia, M.-E. (2011) Forecasting Short-Term Freight Rate Cycles: Do We Have a More Appropriate Method than Normal Distribution? Maritime Policy \& Management, 38, 645-672. https://doi.org/10.1080/03088839.2011.556673

[100] Buchanan, M. (2013) Forecast: What Physics, Meteorology and the Natural Sciences Can Teach Us about Economics.

[101] Lucas, R.E. and Sargent, T.J. (1979) After Keynesian Macroeconomics. Federal Reserve Bank of Minneapolis, Minneapolis, 1-16.

[102] Lucas, R.E. (1976) Econometric Policy Evaluation: A Critique. In: Brunner, K. and Meltzer, A., Eds., Carnegie-Rochester Conference Series on Public Policy, Elsevier, Amsterdam, 19-46. https://doi.org/10.1016/S0167-2231(76)80003-6 